\title{
Erratum to: PLIF in thoracolumbar trauma: technique and radiological results
}

Rene Schmid • Dietmar Krappinger •

Peter Seykora $\cdot$ Michael Blauth $\cdot$ Anton Kathrein

Published online: 11 May 2010

(C) Springer-Verlag 2010

\section{Erratum to: Eur Spine J}

\section{DOI 10.1007/s00586-010-1362-5}

There are errors in the authors names of the article.

The correct names are:

Rene Schmid . Dietmar Krappinger - Peter Seykora .

Michael Blauth · Anton Kathrein

The online version of the original article can be found under doi:10.1007/s00586-010-1362-5.

R. Schmid $(\bowtie) \cdot$ D. Krappinger $\cdot$ P. Seykora $\cdot$ M. Blauth Department for Trauma Surgery and Sports Medicine,

Medical University Innsbruck, Anichstraße 35,

6020 Innsbruck, Austria

e-mail: Rene.schmid@uki.at
A. Kathrein
St. Vinzenz Krankenhaus, Zams, Austria 